\title{
Evidensbasert medisin eller vulgærcochranisme?
}

\author{
Evidensbasert medisin har med sine randomiserte studier og metaanalyser hatt enorm betydning for klinisk \\ medisin. Vi har nå langt sikrere kunnskap om hva som virker og hva som ikke virker - og om hva som til \\ og med kan være skadelig. Men evidensbasert medisin er dessverre blitt vulgarisert til bare å handle om \\ evidens og til systematisk nedvurdering av erfaringsbasert kunnskap.
}

Evidensbasert medisin har vist oss at ikkemedikamentelle behandlingsstrategier har bedre effekt enn sovemedisiner ved søvnforstyrrelser hos eldre (1), at rask reduksjon av blodtrykket ved akutt hjerneslag ikke har gunstige effekter (2), at primær innsetting av hemiprotese er bedre enn osteosyntese ved disloserte lårhalsbrudd (3) og at geriatriske enheter og slagenheter har overlegne behandlingsresultater sammenliknet med ordinære sengeposter $(4,5)$ - for bare å nevne noen få norske glanseksempler.

Jeg ønsker ikke å angripe de gode sidene ved evidensbasert medisin og systematiske oversikter med metaanalyser, slik de foregår blant annet i regi av Cochranesamarbeidet - jeg er selv i betydelig grad engasjert i slik forskning. Men dessverre er evidensbasert medisin etter hvert blitt vulgarisert til bare å handle om evidens fremskaffet på én spesiell måte og til systematisk nedvurdering av andre kilder til kunnskap. Det har fått utvikle seg en vulgærcochranisme.

Evidenspyramiden (fig 1) blir publisert overalt og anvendes flittig. På toppen står retningslinjer basert på kvalitetsvurderte systematiske oversikter, $i$ bunnen ligger ekspertvurderingene, som vulgærcochranistene foraktelig kaller GOGAT (good old guys around a table). Ved medisinsk embetseksamen i Oslo har det sågar vært foreslått at studentene skal kunne gjengi pyramidens nivåer og det tilhørende nummereringssystemet for rangering av evidens (6). Denne utviklingen, med overdreven tiltro til evidensbasert medisin, kan ha minst tre konsekvenser (7).

\section{Foreliggende evidens strekkes lenger enn den er gyldig}

Dette skyldes at man i for liten grad tar hensyn til individuelle variasjoner. Relevansen av en randomisert studie eller metaanalyse for en enkeltpasient beror på at pasienten responderer nokså likt som gjennomsnittet av pasientene som var med i studien eller metaanalysen. Men slik er jo ikke pasienter. Jo eldre de blir og jo flere sykdommer de har, desto mer ulike blir de og desto færre av dem likner pasientene i studiene. Den genetisk styrte aldringsprosessen skrider frem med ulik fart, og akkumulerte sykdommer og sekveler påvirker behandlingsresponsen på en svært heterogen

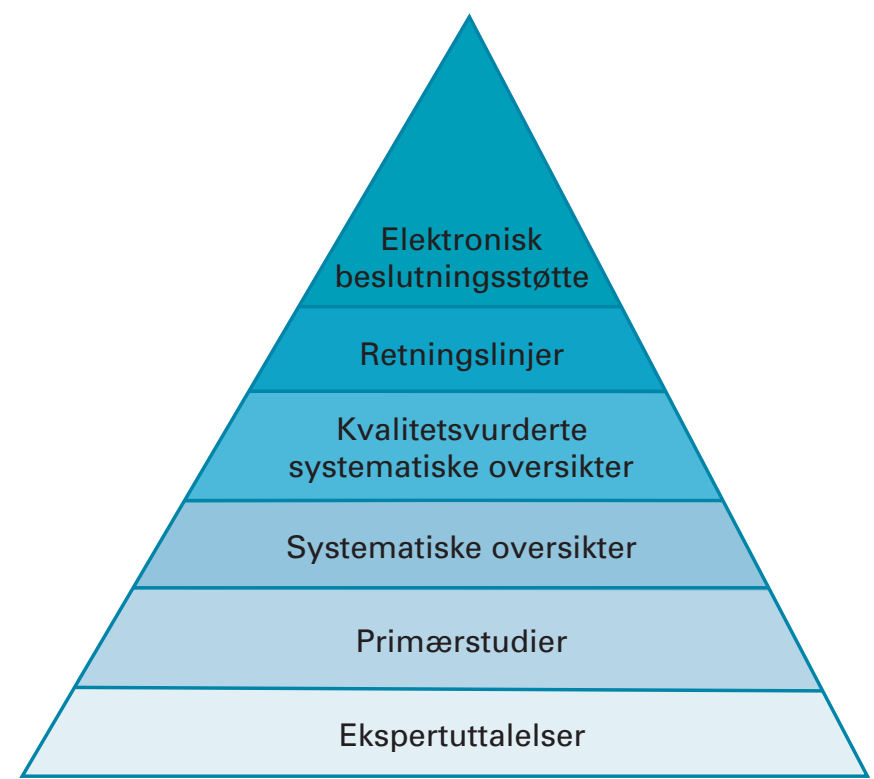

Figur 1 En vanlig brukt rangering av evidens. Plassering høyere opp i trekanten angir større verdi

måte. Vulgærcochranistene vil sikkert også forsikre oss om at man skal tolke relevansen av enkeltstudier inn i det kliniske totalbildet. Men ser man på flommen av kliniske retningslinjer (guidelines) som velter innover oss, eller for den saks skyld på NAVs håndtering av blåreseptordningen, så skjønner man at virkeligheten er blitt en annen.

Randomiserte undersøkelser av legemidler omfatter nesten aldri pasienter som bruker et stort antall andre midler i tillegg til det som skal undersøkes. I evidensbaserte retningslinjer for behandling av definerte sykdommer drøftes i svært liten grad hvordan man skal forholde seg dersom pasienten har kroniske sykdommer i tillegg til den som er tema for retningslinjene (8). Særlig når det gjelder skrøpelige personer med mange sykdommer er det helt avgjørende at evidensen blir filtrert gjennom sunt skjønn og klinisk erfaring. Dette er viktig av to grunner - for det første fordi forskning oftest er utført på pasienter som er lite representative for dem man møter i klinisk praksis, for det andre fordi det kan være en betydelig variasjon i behandlingsrespons selv hos pasienter som likner studiepasientene. Men kliniske retningslinjer, enten de er laget av fagmiljøer, helsemyndigheter eller legemiddelfirmaer, er gjerne svært kategoriske på at pasienter med visse til- stander skal behandles på en helt konkret og såkalt evidensbasert måte. Dette avslører en utilstrekkelig forståelse av biologi og klinisk medisin.

\section{Neglisjering av tiltak der evidens er vanskelig å fremskaffe} I et system der man overfokuserer på evidens i snever forstand, risikerer man at tiltak som etter alle solemerker er fornuftige, blir nedprioritert fordi det ikke er mulig å fremskaffe evidens av en slik karakter at den blir akseptert som gyldig (9).

De som trodde at evidensbasert medisin skulle bli et bolverk mot den farmasøytiske industriens hegemoni, må tro om igjen. Det er blitt enda vanskeligere enn før å klare seg uten et kapitalsterkt farmasøytisk firma i ryggen dersom man ønsker å gjøre forskning som oppfyller cochranistenes kvalitetskrav. Helst bør man forske på en helt standardisert behandling der kontrollgruppen enkelt kan få placebo. Da snakker vi jo nettopp om legemidler. Vi får altså en forsterkning av tendensen til å gripe til farmakologiske løsninger fremfor ikke-farmakologiske tiltak.

\section{Nedvurdering av erfaringsbasert kunnskap}

Denne tredje konsekvensen er den mest alvorlige: Vi mister mønstergjenkjen- 
ningen, intuisjonen, observasjon av de ørsmå detaljene, det som får erfarne klinikere til å skjønne hvordan akkurat denne pasienten bør behandles. Denne kunnskapen har vulgærcochranistene eksplisitt plassert nederst i kunnskapspyramiden. De aner neppe hva man da går glipp av. Det finslipte skjønnet, som det har tatt tiår å kalibrere, kan aldri på en fullgod måte erstattes av systematiske oversikter og metaanalyser. Selvsagt kan man komme på villspor ved bare å basere seg på erfaringer. Heller ikke de må få råde grunnen alene. Men ensidig å avvise klinisk erfaring som fordomsfull/skjev (biased) og uvitenskapelig har vi rett og slett ikke råd til.

\section{Årsaker til vulgærcochranismens fremvekst}

Hvorfor er situasjonen blitt slik den er? Jeg ser minst to årsaker til det. For det første passer vulgærcochranismen som hånd i hanske til byråkratiets måte å tenke på. Erfaringsbasert kunnskap, derimot, er forestillingen om at ens egen måte å produsere kunnskap på er den mest høyverdige og egentlig den eneste gyldige. Det er denne oppfatningen som har tvunget vårt eget tidsskrift til å sette inn den samme meningsløse setningen i hver bidige oversiktsartikkel: «Artikkelen bygger på forfatterens erfaringer kombinert med et usystematisk søk i PubMed og referanser fra forfatterens eget arkiv.» Selvfølgelig! Hvis jeg leser en oversiktsartikkel av Karl O. Nakken om epilepsi (10), en av Bjørn Bjorvatn om søvnforstyrrelser (11) eller en av Espen Molden om medikamentelle interaksjoner (12), da leser jeg den nettopp fordi jeg vil vite hva akkurat Karl O. Nakken, Bjørn Bjorvatn eller Espen Molden mener og hvordan de fortolker forskningen, fordi jeg anser dem som særlig kompetente innen sine respektive felter. Men for at ikke vi andre skal tro at de selv tror de $e r$ noe, så tvinges de alle til å utføre den samme botsøvelsen: $\AA$ innrømme at dette er nok ikke ordentlig kunnskap, det bare noe de mener etter å ha jobbet 20-30-40 år

\section{«Det finslipte skjønnet, som det har tatt tiår å kalibrere, kan aldri på en fullgod måte erstattes av systematiske oversikter og metaanalyser»}

en trussel mot byråkratiet, fordi den er så vanskelig å strømlinjeforme. Forteller du en byråkrat at du kan regne ut med desimaler hva som er sant og hva som er usant for alle, da blir han glad! Pluss gjerne på noen kvalitetsjusterte leveårsberegninger og fortell ham at politiske verdivalg kan omskapes til objektive kalkyler. Da har du god sjanse til å få fast jobb i det statlige helsebyråkratiet.

For det andre tror jeg det må ha noe med oss leger å gjøre. Vi er gjennom mange år blitt sosialisert til lå lære det noen ber oss om å lære. Først ble vi bedt om å pugge tyske kasus, så vi skulle komme inn på medisinstudiet. De av oss som orket å pugge nok, kom inn. Så måtte vi lære strukturformlene for alle aminosyrene og hvor hver enkelt av dem kommer inn i sitronsyresyklus. Så da lærte vi oss det. Kommer noen trekkende med et såkalt DRG-system - revnende likegyldig som det er for kvaliteten på vårt kliniske virke - ja så pugger vi også det. Er det rart vi blir betatt av modernismens prosjekt, der det finnes objektive hierarkier for grad av sannhet (6)?

Hva skiller vulgærcochranismen fra sunn evidensbasert medisin? Et viktig kriterium er i feltet. Det er GOGAT, det har slagside, det er laveste trinn i evidenshierarkiet.

Likeledes er det vulgærcochranismen som har gjort finansieringen av Norsk legemiddelhåndbok så vanskelig. Dette enestående dugnadsprosjektet, der flere hundre norske eksperter - uavhengig av både produsenter og myndigheter - tolker tilgjengelig evidens til nytte for norske klinikere, er ikke lenger politisk korrekt. Boken er nemlig basert på en anerkjennelse av andre kunnskapskilder i tillegg til metaanalysene og den evidensgraderingen som har fătt monopol på sannheten (6).

Som sir David Lawrence Sackett, kanadisk lege og en av pionerene i evidensbasert medisin, uttrykte for drøyt ti år siden: «Evidence-based medicine is the integration of best research evidence with clinical expertise and patient values» (13). Noen må ta ansvar for å bringe evidensbasert medisin tilbake på plass, slik at vi igjen kan få en sunn balanse mellom ulike kilder for kunnskap.

\section{Torgeir Bruun Wyller}

t.b.wyller@medisin.uio.no

Institutt for klinisk medisin

Universitetet i Oslo
Torgeir Bruun Wyller (f. 1960) er spesialist i indremedisin og geriatri, professor i geriatri ved Universitetet i Oslo og overlege ved Geriatrisk avdeling, Oslo universitetssykehus. Oppgitte interessekonflikter: Forfatteren har fått forelesningshonorar fra Astra, Roche og Pfizer.

Litteratur

1. Sivertsen B, Omvik S, Pallesen S et al. Cognitive behavioral therapy vs zopiclone for treatment of chronic primary insomnia in older adults: a randomized controlled trial. JAMA 2006; 295 : 2851-8.

2. Sandset EC, Bath PM, Boysen $G$ et al. The angiotensin-receptor blocker candesartan for treatment of acute stroke (SCAST): a randomised, placebo-controlled, double-blind trial. Lancet 2011: 377: 741-50.

3. Frihagen F, Nordsletten L, Madsen JE. Hemiarthroplasty or internal fixation for intracapsular displaced femoral neck fractures: randomised controlled trial. BMJ 2007: 335: 1251-4.

4. Saltvedt I, Mo ES, Fayers $P$ et al. Reduced mortality in treating acutely sick, frail older patients in a geriatric evaluation and management unit. A prospective randomized trial. J Am Geriatr Soc 2002; 50: 792-8.

5. Indredavik B, Bakke F, Solberg R et al. Benefit of a stroke unit: a randomized controlled trial. Stroke 1991; 22: 1026-31

6. Harbour R, Miller J. A new system for grading recommendations in evidence based guidelines. BMJ 2001; 323: 334-6.

7. Evans JG. Evidence-based and evidence-biased medicine. Age Ageing 1995; 24: 461-3.

8. Boyd CM, Darer J, Boult $C$ et al. Clinical practice guidelines and quality of care for older patients with multiple comorbid diseases: implications for pay for performance. JAMA 2005; 294: 716-24.

9. Smith GC, Pell JP. Parachute use to prevent death and major trauma related to gravitational challenge: systematic review of randomised controlled trials. BMJ 2003; 327: 1459-61.

10. Nakken KO, Taubøll E. Farmakoresistent epilepsi. Tidsskr Nor Legeforen 2009: 129: 1986-9.

11. Bjorvatn B. Sivertsen B, Øyane N et al. Insomni. Tidsskr Nor Legeforen 2009; 129: 1766-8

12. Molden E, Spigset O. Tobakksrøyking og interaksjoner med legemidler. Tidsskr Nor Legeforen 2009: 129: 632-3.

13. Sackett DL, Strauss SE, Richardson WS et al. Evidence-based medicine - how to practice EBM. Edinburgh: Churchill Livingstone, 2000.

Mottatt 14.3. 2011, første revisjon innsendt 23.4. 2011, godkjent 26.5. 2011. Medisinsk redaktør Petter Gjersvik. 